\title{
Identification of Potential Bacteria on Several Lakes in East Java, Indonesia Based on 16S rRNA Sequence Analysis
}

\author{
Achmad Rodiansyah ${ }^{1}$, Ainul Fitria Mahmudah ${ }^{1}$, Mastika Marisahani Ulfah ${ }^{1}$, Uun Rohmawati ${ }^{1}$, Dwi Listyorini ${ }^{1}$, \\ Eko Agus Suyono², Sitoresmi Prabaningtyas ${ }^{1 *}$
}

${ }^{1}$ Department of Biology, Faculty of Mathematics and Natural Science, Universitas Negeri Malang, Malang, Indonesia

${ }^{2}$ Faculty of Biology, Universitas Gadjah Mada, Yogyakarta, Indonesia

\section{ARTICLE INFO}

\section{Article history:}

Received October 30, 2020

Received in revised form February 10, 2021

Accepted February 15, 2021

\section{KEYWORDS:}

Amylolytic bacteria, cellulolytic bacteria,

indole acetic acid (IAA)-producing bacteria, phosphate solubilizing bacteria (PSB), 16S rRNA

\begin{abstract}
Four bacterial isolates from Ranu Pani and Ranu Grati in east java had been revealed to be potentials to produce IAA (PIS isolate), phosphate solubilizer (GPS isolate), cellulose hydrolysis (PSS isolate) and, amylum hydrolysis (PAS), two dominant bacterial isolates from Rani Pani (PØD isolate) and Ranu Grati (GØD isolate) which were co-cultured with microalgae promoted microalgae growth, yet its taxonomical position has not been clearly known. The aim of this study was to identify those bacterial isolates using 16S rRNA barcode. This research conducted by gDNA isolation, the 16S rRNA sequence was amplified using $27 \mathrm{~F}$ and 1492R primers. Reconstructed phylogenetic trees and genetic distance analysis showed that the isolate PIS and PSS identified as Bacillus cereus Group closely related to Bacillus paramycoides. PAS isolate identified as Bacillus subtilis Group closely related to Bacillus amyloliquefaciens, GPS isolate identified as novel species in genus Enterobacter, and two dominant isolates (PØD and GØD) identified as Enterobacter cloacae complex closely related to Enterobacter cloacae. The genomic approach and additional phenotypes-examination are required to clarify its taxonomical position.
\end{abstract}

\section{Introduction}

The previous research was found 96 bacterial isolates from Ranu Pani, Ranu Regulo, Ranu Grati, and Telaga Ngebel which have multiple potencies as follows, 40 isolates have the potency to produce IAA, 31 phosphate solubilizing bacterias, two dominant bacterias from Ranu Pani and Ranu Grati can promote microalgae growth (Prabaningtyas et al. 2018a, 2018b), 47 cellulolytic bacterias (Ardilla 2018), and 53 amylolytic bacterias (Basitoh 2018). Identification of bacteria that have the highest potential for producing IAA and solubilizing phosphate yet not been done. Moreover, the results of identification based on morphology and physiology of highest amylolytic bacteria identified as Bacillus subtilis (Basitoh 2018), highest cellulolytic bacteria identified as Bacillus alvei (Ardilla 2018), and identification of dominant bacteria from Ranu Grati identified as Enterobacter gergoviae and dominant bacteria from Ranu Pani

\footnotetext{
* Corresponding Author

E-mail Address: sitoresmi.prabaningtyas.fmipa@um.ac.id
}

cannot be identified (Prabaningtyas and Witjoro 2017).

The identification of microorganisms important for microbiologists and scientists involved in many fields of research and applied industry (Bisen et al. 2012). This identification of potential bacteria has beneficial for biological conservation, regulation study, biological activity, and especially in a consortium of bacterial in co-culture microalgae. The consortium of bacteria in co-culture microalgae can increase the efficiency of biomass production from microalgae (Fuentes et al. 2016; Ramanan et al. 2016). This consortium can increase the growth of algae because bacteria provide inorganic essential mineral elements (Marañón et al. 2005; Thyssen 2005) like carbon that needed for metabolic algae (Jena et al. 2011; Kropat et al. 2011).

The identification of bacteria based on the phenotype has been carried out, but this identification method needs more time and energy (López-Campos et al. 2012), different environmental conditions may decreases the validity (Tshikhudo et al. 2013), some bacteria difficult to be cultured so that identification 
cannot be done (Gugliandolo et al. 2011), and there are some morphological and physiological similarities that are difficult to be distinguished (Boivin-Jahns et al. 1995). A fast and reliable method is widely used to overcome this problem by analyzing the barcode 16S rRNA gene (Buszewski et al. 2017; Tshikhudo et al. 2013).

DNA barcoding is an efficient, accurate, cheap and standardized method for identifying organisms using short DNA sequences from whole-genome DNA in the sample (Cristescu 2014; Lebonah et al. 2014). This method can be used to deepen the understanding of ecology, biodiversity, evolution, taxonomy, and conservation (Hanner et al. 2011). The 16S rRNA gene is one of the barcode genes which is usually used to identify bacteria and its population. That gene was chosen because has an informative area and enough variation to distinguish between taxa in the taxon (Wang and Qian 2009). 16S rRNA sequences can be found in all prokaryotic cells with 1-15 copies (Werner et al. 2012; Rosselli et al. 2016), and have widely used in microbial community studies (Rosselli et al. 2016). The use of this gene depends on significant differences in base sequence between species and fewer differences in species (Woo et al. 2009) so it can be used to estimate the genetic distance between species.

\section{Materials and Methods}

\subsection{Isolates}

Six bacterial isolates were obtained from the previous study has various highest potential (Listed in Table 1), those isolates were already in the Laboratory of Microbiology, Department of Biology, Universitas Negeri Malang. Each isolate was cultured on $5 \mathrm{ml}$ nutrient broth and incubated in incubator for overnight at $37^{\circ} \mathrm{C}$. These bacterial cultures were used for genome DNA (gDNA) isolation.

Table 1. Bacterial isolates in this study

\begin{tabular}{lll}
\hline Code & Source & Potential \\
\hline PIS & Ranu Pani & IAA-Producer \\
GPS & Ranu Grati & Phosphate solubilizer \\
PSS & Ranu Pani & Cellulolytic \\
PAS & Ranu Pani & Amylolytic \\
PøD & Ranu Pani & Growth promoter \\
GØD & Ranu Grati & Growth promoter \\
\hline
\end{tabular}

\section{2. gDNA Isolation and 16S rRNA Amplification}

The gDNA from each sample was isolated using the QIAmp DNA Mini Kit (Qiagen, Germany). The result from gDNA isolation was measured using NanoDrop ND-2000 Spectrophotometer (ThermoScientific ${ }^{\mathrm{TM}}$ ) to determine the concentration and purity of gDNA. The results from gDNA isolation were used as a template in the Polymerase Chain Reaction (PCR) to amplification the 16S rRNA sequence. Top Taq Master Mix reagents from Qiagen were used for PCR. Primers used for amplification are 27F: 5'-GAGTTTGATCMTGGCTCAG-3' and 1492R: 5'-ACGGYTACCTTGTTACGACTT-3' (Devereux and Willis 2004; Wang and Qian 2009). The PCR reaction for 30 cycles was performed as follows: initial denaturation $94^{\circ} \mathrm{C} / 3 \mathrm{~min}$, denaturation $94^{\circ} \mathrm{C} / 1 \mathrm{~min}$, annealing $50^{\circ} \mathrm{C} / 30 \mathrm{~s}$, extension $72^{\circ} \mathrm{C} / 1 \mathrm{~min} 30 \mathrm{~s}$, final extension $72^{\circ} \mathrm{C} / 10 \mathrm{~min}$, and hold $4^{\circ} \mathrm{C}$. The PCR product was checked on $1 \%$ agarose gel electrophoresis.

\subsection{DNA Sequencing, Phylogenetic Trees Reconstruction and Genetic Distance Analysis}

The PCR products were determined by DNA sequencing in $1^{\text {st }}$ BASE Laboratories, Malaysia. Sequencing results were analyzed using DNA baser software to determine sequence consensus and sequence alignment using BLAST program on NCBI (https://blast.ncbi.nlm.nih.gov/Blast.cgi). Phylogenetic trees reconstruction and genetic distance were analyzed using MEGA6 software. The phylogenetic trees were constructed using NeighborJoining (NJ) method (Saitou and Nei 1987) and Minimum-Evolution (ME) method (Rzhetsky and Nei 1992). The evolutionary distances were calculated using Kimura 2-parameter method (Kimura 1980) with bootstrap test 1,000 replicates (Felsenstein, 1985).

\section{Results}

\subsection{Genome DNA Isolation and PCR}

Total gDNA obtained from isolation had the various purity and concentration from each isolate (Table 2). The PCR result showed that band DNA in gel electrophoresis has a target gene with length about 1500 bp (Figure 1) and then verified by DNA sequencing. 


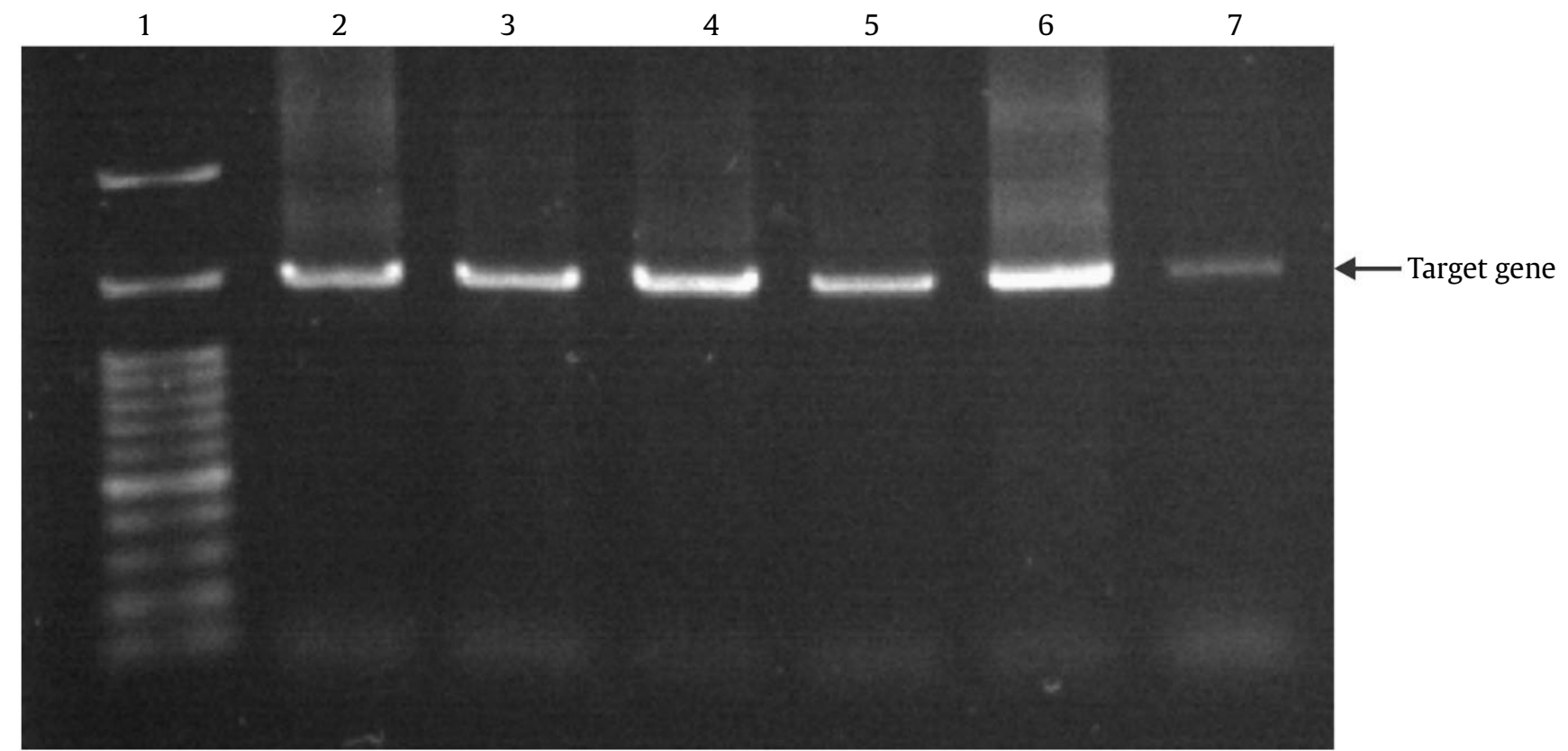

Figure 1. Electrophoregram of 16S rRNA gene amplification on gel electrophoresis 1 percent. Each sample was located from lane 1 to 6 (DNA marker 100 bp from Geneaid, PIS, GPS, PAS, PSS, PØD, GØD, respectively)

Table 2. Concentration and purity of gDNA

\begin{tabular}{lcc}
\hline Code & Concentration $(\mathrm{ng} / \mathrm{\mu l})$ & $\mathrm{A}_{260} / \mathrm{A}_{280}$ \\
\hline PIS & 231.5 & 1.98 \\
GPS & 65.7 & 1.97 \\
PAS & 46.5 & 1.94 \\
PSS & 253.8 & 2.01 \\
PØD & 234.3 & 1.84 \\
GØD & 291.0 & 2.08 \\
\hline
\end{tabular}

\subsection{DNA Sequencing and Sequence Analysis}

Consensus sequence length from DNA sequencing listed in Table 3. BLAST analysis from all consensus sequences showed that they have high similarity and high query coverage with $16 \mathrm{~S}$ rRNA sequence on the NCBI database. Several similar sequences from BLAST were downloaded and used for phylogenetic trees reconstruction and genetic distance analysis.

\subsection{Phylogenetic Trees Reconstruction and Genetic Distance Analysis}

Phylogenetic trees reconstruction using $\mathrm{NJ}$ and ME showed that three main clades and one clade as out of the group, these three main clades are Enterobacter clade (red line), Bacillus cereus Group clade (blue line), and Bacillus subtilis Group clade (green line) (Figure 2a and $b$ ). The PIS and PSS isolates were located in Bacillus cereus Group clade, with bootstrap value NJ:100 and ME:100, the PAS isolate was located in Bacillus subtilis Group clade, with bootstrap value NJ:82 and ME: 83, the GPS isolate located on Enterobacter clade with bootstrap value NJ:100 and ME:100, PØD and GØD
Table 3. Consensus sequences length from DNA sequencing

\begin{tabular}{lc}
\hline Code & Sequence length (bp) \\
\hline PIS & 1431 \\
GPS & 1423 \\
PAS & 1424 \\
PSS & 1420 \\
PØD & 1333 \\
GØD & 1416 \\
\hline
\end{tabular}

isolates identified as Enterobacter cloacae a member of Enterobacter cloacae Complex (ECC) with bootstrap value NJ:61 and ME:62.

Phylogenetic trees showed a correlation with genetic distance analysis. Three main clades in Figure 2 have a significant genetic distance value there are indicating a different genus. Group Enterobacter cloacae Complex has genetic distance value 0.270 with Bacillus subtilis Group and 0.258 with Bacillus cereus Group (black box in Figure 3). It means there's are 73.0-74.2\% sequences similarity in the Enterobacter group with both genus Bacillus so that clearly defined as a different genus. Bacillus cereus Group has a genetic distance value 0.060 or $94 \%$ similarity with the Bacillus subtilis Group (red box in Figure 3), so as for them separate in sub-genus level.

Analysis of genetic distance in PIS and PSS samples identified in one species to members species of Bacillus cereus Group with similarity 99.9-100\% (red square in Figure 4), and these samples located in the Bacillus cereus Group's clade. PAS sample is located in Bacillus subtilis Group's clade and this sample identified as $B$. amyloliquefaciens with $100 \%$ similarity but it has closely 
a

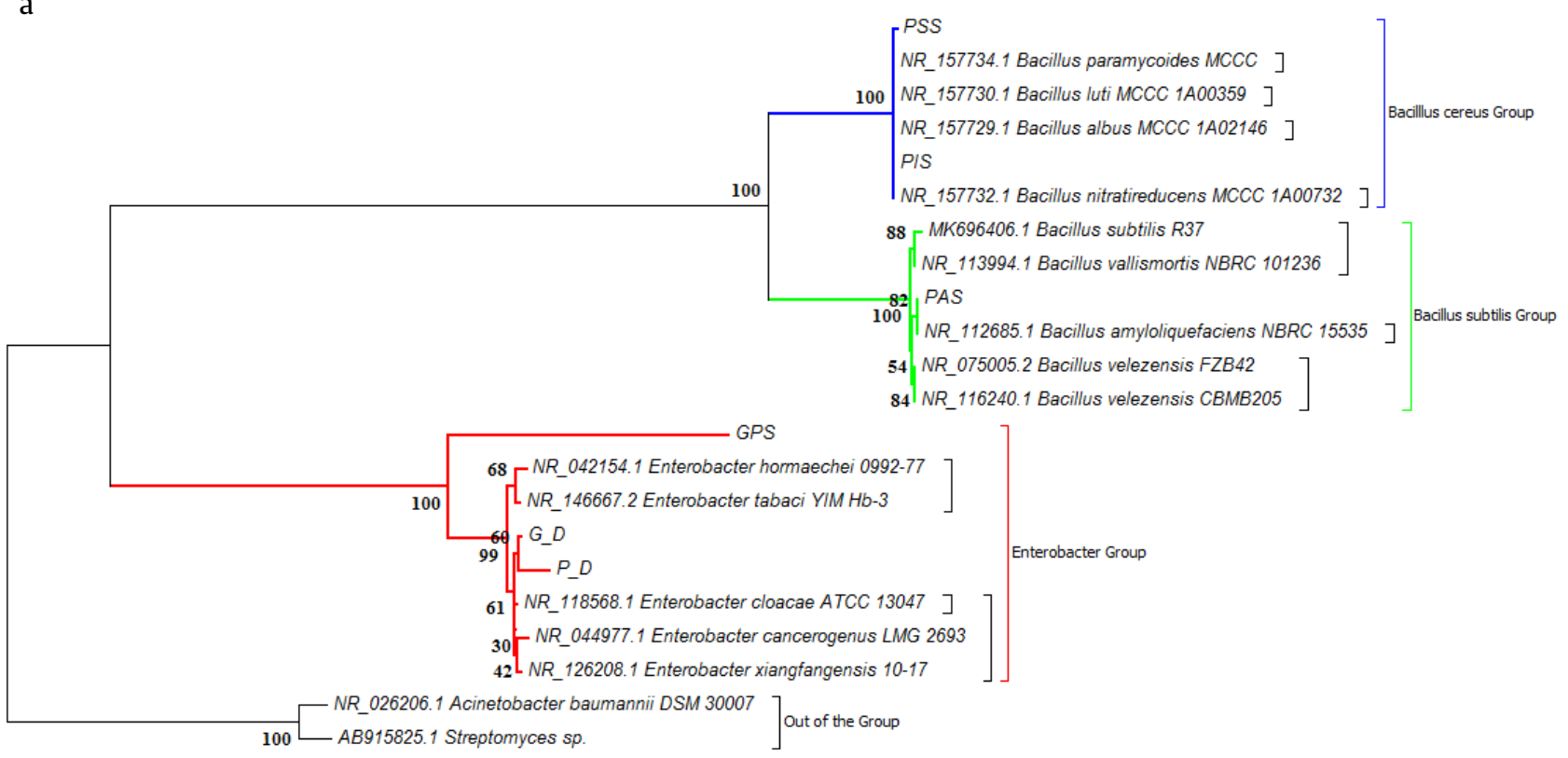

$\longmapsto$

b

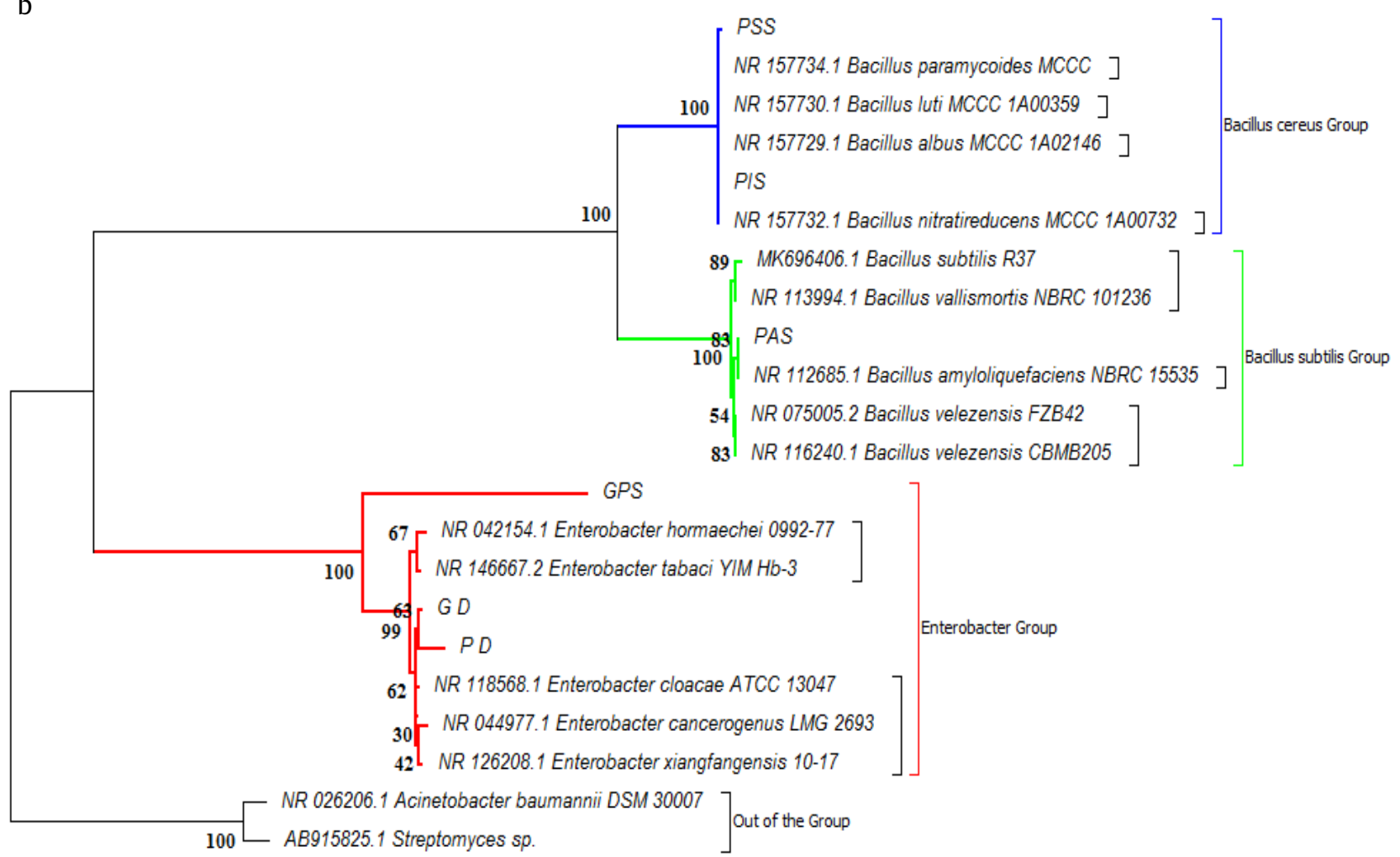

$\vdash_{0.02}$

Figure 2. Phylogenetic trees based on 16S rRNA gene, (a) NJ tree, (b) ME tree. The trees were constructed with 1,000 replicates using Kimura 2-parameter model and Acinetobacter baumannii and Streptomyces sp. were used as an out of the group 
related to with $B$. subtilis, B. velezensis, and B. vallismortis with similarity $>99.8 \%$ (black square in Figure 4 ).

The genetic distance of the GPS sample has a similarity $<95 \%$ with another species in genus Enterobacter, this result indicated that GPS sample cannot be defined as species but defined in the genus level (blue square in Figure 4). The genetic distance of PØD and GØD samples were defined as Enterobacter cloacae complex with similarity $>99 \%$, but these samples were closely related to Enterobacter cloacae with similarity values $99.8 \%$ on GØD and 99.2\% on PØD (yellow box in Figure 4). Intraspecific genetic distance analysis showed that there's are no significant variation 16S rRNA sequences within groups, so the sequences variety each group are relatively homogeneous with similarity $>99 \%$ (Figure $5)$.

\begin{tabular}{|c|c|c|c|c|c|c|c|}
\hline 賟 & 慗 & $(A, B)$ & $\begin{array}{l}0.0 \\
n^{2}\end{array}$ & in & 且 & $\bar{X}$ & CSV \\
\hline & & & 1 & 2 & 3 & 4 & \\
\hline \multicolumn{3}{|c|}{ 1. Enterobacter Group } & & 0.015 & 0.015 & 0.012 & \\
\hline \multicolumn{3}{|c|}{ 2. Bacillus subtilis Group } & 0.270 & & 0.007 & 0.015 & \\
\hline \multicolumn{3}{|c|}{ 3. Bacillus cereus Group } & 0.258 & 0.060 & & 0.015 & \\
\hline \multicolumn{3}{|c|}{ 4. Out of the Group } & 0.174 & 0.261 & 0.260 & & \\
\hline
\end{tabular}

Figure 3. Genetic distance between the group. The standard error(s) are shown in the cross of genetic distance calculation (blue text), these analyses were conducted using Kimura 2-parameter with 1,000 replicates

\section{Discussion}

Phylogenetic trees reconstruction revealed that PSS and PIS samples were located in clade with Bacillus cereus Group and PAS sample located in Bacillus substilis Group closely to Bacillus amyloliquefaciens NBRC 15535, GØD and PØD located in Enterobacter cloacae Complex, while GPS is located in Enterobacter clade with form a new clade (can be defined as novel Enterobacter) (Figure 2). All of the branches from phylogenetic trees show a confident po sition with trusted bootstrap value of $>50$ (Gregory 2008). The position of each sample in the phylogenetic tree showed a correlation with genetic distance analysis. Almost all of them were separated in a new clade as a group supported by its significant genetic distance (Figure 3), and within-group genetic distance (>99\%)

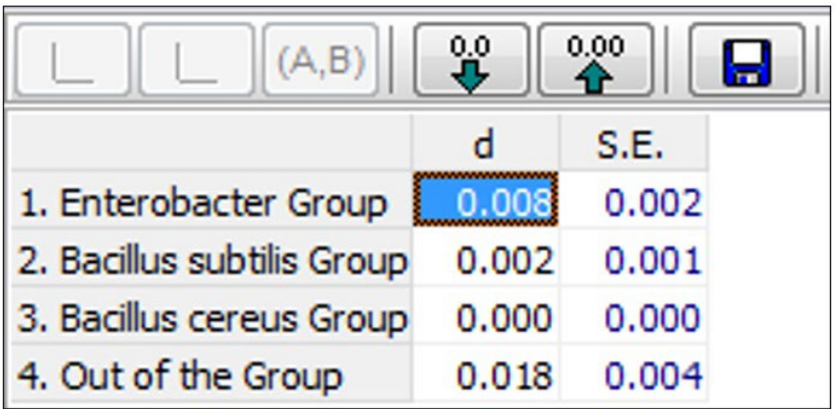

Figure 5. Genetic distance analysis within the group. The standard error(s) are shown in the second column, these analyses were conducted using Kimura 2-parameter with 1,000 replicates

\begin{tabular}{|c|c|c|c|c|c|c|c|c|c|c|c|c|c|c|c|c|c|c|c|c|c|c|c|c|c|}
\hline $\mathbf{A} \mathbf{D}(\mathrm{A}, \mathrm{B})$ & $\Leftrightarrow$ & 900 & 日 & $\left.\mathrm{CSO}^{7}\right]$ & mith & 8 & & & & & & & & & & & & & & & & & & & \\
\hline & & & & 1 & 2 & 3 & 4 & 5 & 6 & 7 & 8 & 9 & 10 & 11 & 12 & 13 & 14 & 15 & 16 & 17 & 18 & 19 & 20 & 21 & 22 \\
\hline \multicolumn{4}{|l|}{1.6 .0} & & 0.002 & 0.008 & 0.017 & 0.017 & 0.018 & 0.002 & 0.002 & 0.001 & 0.002 & 0.002 & 0.018 & 0.018 & 0.018 & 0.018 & 0.018 & 0.017 & 0.017 & 0.017 & 0.017 & 0.013 & 0.013 \\
\hline \multicolumn{4}{|l|}{ 2.PDD } & 0.007 & & 0.008 & 0.018 & 0.018 & 0.018 & 0.003 & 0.003 & 0.003 & 0.003 & 0.003 & 0.018 & 0.018 & 0.018 & 0.018 & 0.018 & 0.018 & 0.018 & 0.018 & 0.018 & 0.013 & 0.013 \\
\hline \multicolumn{4}{|l|}{ 3. GPS } & 0.076 & 0.081 & & 0.020 & 0.020 & 0.020 & 0.008 & 0.008 & 0.008 & 0.008 & 0.008 & 0.020 & 0.020 & 0.020 & 0.020 & 0.020 & 0.020 & 0.020 & 0.020 & 0.020 & 0.015 & 0.016 \\
\hline \multicolumn{4}{|l|}{ 4. PIS } & 0.258 & 0.264 & 0.305 & & 0.001 & 0.007 & 0.017 & 0.018 & 0.017 & 0.017 & 0.017 & 0.007 & 0.007 & 0.007 & 0.007 & 0.007 & 0.000 & 0.000 & 0.000 & 0.000 & 0.017 & 0.017 \\
\hline \multicolumn{4}{|l|}{ 5. PSS } & 0.259 & 0.265 & 0.306 & 0.001 & & 0.007 & 0.017 & 0.018 & 0.017 & 0.017 & 0.017 & 0.007 & 0.007 & 0.007 & 0.007 & 0.007 & 0.001 & 0.001 & 0.001 & 0.001 & 0.017 & 0.017 \\
\hline \multicolumn{4}{|l|}{ 6. PAS } & 0.270 & 0.276 & 0.312 & 0.060 & 0.061 & & 0.018 & 0.018 & 0.018 & 0.018 & 0.017 & 0.001 & 0.000 & 0.002 & 0.001 & 0.001 & 0.007 & 0.007 & 0.007 & 0.007 & 0.017 & 0.017 \\
\hline \multicolumn{4}{|c|}{ 7. NR_042154.1 Enter obacter hormaechei 0992-77 } & 0.006 & 0.013 & 0.078 & 0.259 & 0.260 & 0.271 & & 0.002 & 0.002 & 0.002 & 0.002 & 0.018 & 0.018 & 0.018 & 0.018 & 0.018 & 0.017 & 0.017 & 0.017 & 0.017 & 0.013 & 0.013 \\
\hline \multicolumn{4}{|c|}{ 8. IR_044977. 1 Enterobacter cancerogenus LMG 2693} & 0.005 & 0.011 & 0.077 & 0.261 & 0.262 & 0.270 & 0.008 & & 0.002 & 0.002 & 0.003 & 0.018 & 0.018 & 0.018 & 0.018 & 0.018 & 0.018 & 0.018 & 0.018 & 0.018 & 0.013 & 0.013 \\
\hline \multicolumn{4}{|c|}{ 9. NR_118568.1 Enterobacter doacse ATCC 13047} & 0.002 & 0.008 & 0.076 & 0.257 & 0.258 & 0.269 & 0.007 & 0.004 & & 0.001 & 0.002 & 0.018 & 0.018 & 0.017 & 0.018 & 0.018 & 0.017 & 0.017 & 0.017 & 0.017 & 0.013 & 0.013 \\
\hline \multicolumn{4}{|c|}{ 10. NR_126208.1 Enterobacter xiangfangensis $10-17$} & 0.004 & 0.010 & 0.075 & 0.258 & 0.259 & 0.270 & 0.005 & 0.003 & 0.002 & & 0.003 & 0.018 & 0.018 & 0.018 & 0.018 & 0.018 & 0.017 & 0.017 & 0.017 & 0.017 & 0.013 & 0.013 \\
\hline \multicolumn{4}{|c|}{ 11. NR_146667.2 Enterobacter tabad YM Hb-3 } & 0.006 & 0.013 & 0.080 & 0.258 & 0.259 & 0.267 & 0.003 & 0.009 & 0.007 & 0.008 & & 0.017 & 0.017 & 0.017 & 0.017 & 0.017 & 0.017 & 0.017 & 0.017 & 0.017 & 0.013 & 0.013 \\
\hline \multicolumn{4}{|c|}{ 12. NR_ 075005.2 Baclus velezensis F2B 42} & 0.270 & 0.276 & 0.310 & 0.059 & 0.060 & 0.002 & 0.271 & 0.270 & 0.269 & 0.270 & 0.267 & & 0.001 & 0.002 & 0.001 & 0.000 & 0.007 & 0.007 & 0.007 & 0.007 & 0.017 & 0.017 \\
\hline \multicolumn{4}{|c|}{ 13. NR_112685. 1 Baolus amyloiquefacens NBRC 15535} & 0.270 & 0.276 & 0.312 & 0.060 & 0.061 & 0.000 & 0.271 & 0.270 & 0.269 & 0.270 & 0.267 & 0.002 & & 0.002 & 0.001 & 0.001 & 0.007 & 0.007 & 0.007 & 0.007 & 0.017 & 0.017 \\
\hline \multicolumn{4}{|c|}{ 14. MK696406.1 Baclus subtlis R.37 } & 0.270 & 0.276 & 0.313 & 0.061 & 0.062 & 0.004 & 0.273 & 0.270 & 0.268 & 0.270 & 0.270 & 0.004 & 0.004 & & 0.001 & 0.002 & 0.007 & 0.007 & 0.007 & 0.007 & 0.017 & 0.017 \\
\hline \multicolumn{4}{|c|}{ 15. NR_113994. 1 Baclus valsmorts NERC 101236} & 0.272 & 0.279 & 0.312 & 0.059 & 0.060 & 0.002 & 0.273 & 0.272 & 0.271 & 0.272 & 0.270 & 0.002 & 0.002 & 0.002 & & 0.001 & 0.007 & 0.007 & 0.007 & 0.007 & 0.017 & 0.017 \\
\hline \multicolumn{4}{|c|}{ 16. NR_116240.1 Baclus velezensis CBMB205 } & 0.270 & 0.276 & 0.310 & 0.059 & 0.060 & 0.002 & 0.271 & 0.270 & 0.269 & 0.270 & 0.267 & 0.000 & 0.002 & 0.004 & 0.002 & & 0.007 & 0.007 & 0.007 & 0.007 & 0.017 & 0.017 \\
\hline \multicolumn{4}{|c|}{ 17. NR_157729.1 Baclus abus MCCC 1402146} & 0.258 & 0.264 & 0.305 & 0.000 & 0.001 & 0.060 & 0.259 & 0.261 & 0.257 & 0.258 & 0.258 & 0.059 & 0.060 & 0.061 & 0.059 & 0.059 & & 0.000 & 0.000 & 0.000 & 0.017 & 0.017 \\
\hline \multicolumn{4}{|c|}{ 18. NR_157730.1 Baclus LV MCCC 1400359} & 0.258 & 0.264 & 0.305 & 0.000 & 0.001 & 0.060 & 0.259 & 0.261 & 0.257 & 0.258 & 0.258 & 0.059 & 0.060 & 0.061 & 0.059 & 0.059 & 0.000 & & 0.000 & 0.000 & 0.017 & 0.017 \\
\hline \multicolumn{4}{|c|}{ 19. NR_157732.1 Baclus nitratreducens MCCC 1400732} & 0.258 & 0.264 & 0.305 & 0.000 & 0.001 & 0.060 & 0.259 & 0.261 & 0.257 & 0.258 & 0.258 & 0.059 & 0.060 & 0.061 & 0.059 & 0.059 & 0.000 & 0.000 & & 0.000 & 0.017 & 0.017 \\
\hline \multicolumn{4}{|c|}{ 20. NR_157734.1 Baclus paramycoides MCCC } & 0.258 & 0.264 & 0.305 & 0.000 & 0.001 & 0.060 & 0.259 & 0.261 & 0.257 & 0.258 & 0.258 & 0.059 & 0.060 & 0.061 & 0.059 & 0.059 & 0.000 & 0.000 & 0.000 & & 0.017 & 0.017 \\
\hline \multicolumn{4}{|c|}{ 21. NR_026206.1 Achetobacter baumami DSM 30007} & 0.175 & 0.178 & 0.234 & 0.266 & 0.268 & 0.266 & 0.176 & 0.176 & 0.174 & 0.175 & 0.175 & 0.267 & 0.266 & 0.267 & 0.267 & 0.267 & 0.266 & 0.266 & 0.266 & 0.266 & & 0.003 \\
\hline \multicolumn{4}{|c|}{ 22. AB915825. 1 Streptonyces $\$$. } & 0.175 & 0.181 & 0.237 & 0.266 & 0.267 & 0.267 & 0.177 & 0.178 & 0.176 & 0.177 & 0.176 & 0.268 & 0.267 & 0.268 & 0.263 & 0.268 & 0.266 & 0.266 & 0.266 & 0.266 & 0.013 & \\
\hline
\end{tabular}

Figure 4. Genetic distance analysis for each sample. The standard error(s) are shown in the cross of genetic distance calculation (blue text), these analyses were conducted using Kimura 2-parameter with 1,000 replicates 
(Figure 5). The Genetic distance value between $\leq 0.03$ defined in one species, genetic distance $\leq 0.05$ defined in one genus, defined in one class if $\leq 0.15$, and 0.20-0.40 defined in one phylum (Bukin et al. 2019; Schloss and Handelsman 2004; Truong et al. 2017). Species are organisms with similarity $>97 \%$, the definition of species "match" if similarity $>99 \%$ (Drancourt et al. 2000; Janda and Abbott 2007), and if the similarity has less than $97 \%$ can be defined as novel species (Stackebrandt and Goebel 1994).

Molecular signatures for Bacillus spp. were categorized on several groups based on 16S rRNA, whereas Bacillus substilis Group in clade I and Bacillus cereus Group in clade II (Rooney et al. 2009; Bhandari et al. 2013; Fan et al. 2017). B. amyloliquefaciens, $B$. siamensis, B. velezensis, B. methylotrophicus are a member of the new phylogenetic branch of "operational group Bacillus amyloliquefaciens" from Bacillus substilis Species Complex (Fan et al. 2017). Identification based on morphology and physiology in the previous study PAS sample identified as B. substilis (Basitoh 2018) but with 16S rRNA, we can identify more deeply to $B$. amyloliquefaciens NBRC 15535. This species can hydrolyze amylum using amylase enzymes (Deb et al. 2013). In the other group of Bacillus spp., Bacillus cereus Group or ( $B$. cereus sensu lato) is sub-division in genus Bacillus, this group include $B$. anthracis, $B$. cereus, $B$. mycoides, B. pseudomycoides, $B$. weihenstephanensis, $B$. thuringiensis, $B$. paranthracis, $B$. pacificus, $B$. tropicus, B. albus, B. mobilis, B. luti, B. proteolyticus, B. nitratireducens, B. paramycoides (Nakamura and Jackson 1995; Vilas-Bôas et al. 2007; Liu et al. 2017). Most species in genus Bacillus can produce IAA (Patten et al. 2013; Liu et al. 2017; Ozdal et al. 2017; Susilowati et al. 2018) via dependent pathways with tryptophan as a precursor (Spaepen et al. 2007; Shao et al. 2015) and also cellulose hydrolysis (Balasubramanian et al. 2012; Gupta et al. 2012; Lin et al. 2012; Chantarasiri 2015) with celluloses enzyme group such as endoglucanase, exoglucanase, and $\beta$-glucosidase (Bayer et al. 2007). The little genetic diversity on those group Bacillus, identification on species-level mostly cannot be defined with $16 \mathrm{~S}$ rRNA (Rasko et al. 2005; Rooney et al. 2009).

In the Enterobacter clade, sample GPS identified as novel species in genus Enterobacter with similarity below $95 \%$. In the research progress with that isolate, confirmed that Pho regulon includes phoA, phoB, and phoR genes are probably act on solubilizing of complex phosphates (Ongoing research, data not published). Two dominant isolates (GØD and PØD) are located one clade with Enterobacter cloacae ATTC 13047 and they have $>99 \%$ similarity within group ECC, so it makes identification on species-level probably bias. Some species in genus Enterobacter, especially ECC has multiple potentials such as solubilizing phosphate, produce IAA, and produce ammonia (Nhu and Diep 2017).

This research has shown the PIS and PSS isolates were identified as Bacillus cereus Group closely related with Bacillus paramycoides, PAS isolate identified as Bacillus amyloliquefaciens which is a member of Bacillus substilis Group, GPS isolate identified as novel species in Enterobacter, and GØD and PØD isolates identified as Enterobacter cloacae which is a member of ECC. The $16 \mathrm{~S}$ rRNA sequence can be defining samples in sub-genus or group within a genus level. Species can be defined but not trusted. Other barcodes/marker genes are required to identification species-level in this group. Identification based on whole-genome sequencing, plasmid characterization, phenotypes characterization, and their combination are required to determining the further classification of species (Konstantinidis and Tiedje 2005; Woo et al. 2009; Tindall et al. 2010; Brady et al. 2013).

\section{Acknowledgements}

The authors would like to extend our grateful to the Direktorat Riset dan Pengabdian Masyarakat (DRPM), Direktorat Jenderal Penguatan Riset dan Pengemembangan from Ministry of Research and Technology Republic Indonesia for funding this research.

\section{References}

Ardilla R. 2018. Isolasi bakteri selulolitik potensial dari Ranu Pani, Ranu Regulo, Ranu Grati, dan Telaga Ngebel [Thesis]. Malang, Indonesia: Universitas Negeri Malang,

Balasubramanian N et al. 2012. Purification and biochemical characterization of a novel thermo-stable carboxymethyl cellulase from Azorean isolate Bacillus mycoides S122C. Appl Biochem Biotechnol 168:21912204.

Basitoh YK. 2018. Eksplorasi bakteri amilolitik potensial dari Ranu Pani, Ranu Regulo, Ranu Grati, dan Telaga Ngebel [Thesis]. Malang, Indonesia: Universitas Negeri Malang.

Bayer EA et al. 2007. The potential of cellulases and cellulosomes for cellulosic waste management. Curr Opin Biotechnol 18:237-245. 
Bhandari V et al. 2013. Molecular signatures for Bacillus species: demarcation of the Bacillus subtilis and Bacillus cereus clades in molecular terms and proposal to limit the placement of new species into the genus Bacillus. Int J Syst Evol Microbiol 63:2712-2726.

Bisen PS et al. 2012. Identification and classification of microbes. In: Microbes. New Jersey: John Wiley and Sons Ltd. pp. 275-337.

Boivin-Jahns V et al. 1995. Comparison of phenotypical and molecular methods for the identification of bacterial strains isolated from a deep subsurface environment. Appl Environ Microbiol 61:3400-3406.

Brady $C$ et al. 2013. Taxonomic evaluation of the genus Enterobacter based on multilocus sequence analysis (MLSA): proposal to reclassify E. nimipressuralis and E. amnigenus into Lelliottia gen. nov. as Lelliottia nimipressuralis comb. nov. and Lelliottia amnigena comb. nov., respectively, E. gergoviae and E. pyrinus into Pluralibacter gen. nov. as Pluralibacter gergoviae comb. nov. and Pluralibacter pyrinus comb. nov., respectively, E. cowanii, E. radicincitans, E. oryzae and E. arachidis into Kosakonia gen. nov. as Kosakonia cowanii comb. nov., Kosakonia radicincitans comb. nov., Kosakonia oryzae comb. nov. and Kosakonia arachidis comb. nov., respectively, and E. turicensis, E. helveticus and E. pulveris into Cronobacter as Cronobacter zurichensis nom. nov., Cronobacter helveticus comb. nov. and Cronobacter pulveris comb. nov., respectively, and emended description of the genera Enterobacter and Cronobacter. Syst Appl Microbiol 36:309-319.

Bukin Yu S et al. 2019. The effect of 16S rRNA region choice on bacterial community metabarcoding results. Sci Data 6:190007. DOI:10.1038/sdata.2019.7

Buszewski B et al. 2017. Identification of microorganisms by modern analytical techniques. J AOAC Int 100:16071623.

Chantarasiri A. 2015. Aquatic Bacillus cereus JD0404 isolated from the muddy sediments of mangrove swamps in Thailand and characterization of its cellulolytic activity. Egypt J Aquat Res 41:257-264.

Cristescu ME. 2014. From barcoding single individuals to metabarcoding biological communities: towards an integrative approach to the study of global biodiversity. Trends Ecol Evol 29:566-571.

Deb P et al. 2013. Production and partial characterization of extracellular amylase enzyme from Bacillus amyloliquefaciens P-001. Springerplus 2:154. DOI:10.1186/2193-1801-2-154

Devereux R, Willis SG. 2004. Amplification of ribosomal RNA sequences. In: Akkermans ADL, Van Elsas JD, De Bruijn FJ (Eds.). Molecular Microbial Ecology Manual. Dordrecht: Springer Netherlands. pp. 277-287.

Drancourt M et al. 2000. 16S Ribosomal DNA sequence analysis of a large collection of environmental and clinical unidentifiable bacterial isolates. J Clin Microbiol 38:3623-3630.

Fan B et al. 2017. Bacillus amyloliquefaciens, Bacillus velezensis, and Bacillus siamensis Form an "Operational Group $B$. amyloliquefaciens" within the B. subtilis Species Complex. Front Microbiol 8:22. DOI:10.3389/ fmicb.2017.00022

Felsenstein J. 1985. Confidence limits on phylogenies: an approach using the bootstrap. Evolution 39:783-791.

Fuentes JL et al. 2016. Impact of microalgae-Bacteria interactions on the production of algal biomass and associated compounds. Mar Drugs 14:100. DOI: $10.3390 / \mathrm{md} 14050100$

Gregory TR. 2008. Understanding evolutionary trees. Evolution: Education and Outreach 1:121-137.

Gugliandolo C et al. 2011. Conventional and molecular methods to detect bacterial pathogens in mussels. Lett Appl Microbiol 52:15-21.
Gupta P et al. 2012. Isolation of cellulose-degrading bacteria and determination of their cellulolytic potential. Int J Microbiol 2012:1-5.

Hanner Ret al. 2011. DNA barcoding of billfishes. Mitochondrial DNA 1:27-36.

Janda JM, Abbott SL. 2007. 16S rRNA gene sequencing for bacterial identification in the diagnostic laboratory: pluses, perils, and pitfalls. J Clin Microbiol 45:27612764.

Jena U et al. 2011. Evaluation of microalgae cultivation using recovered aqueous co-product from thermochemical liquefaction of algal biomass. Bioresour Technol 102:3380-3387.

Kimura M. 1980. A simple method for estimating evolutionary rates of base substitutions through comparative studies of nucleotide sequences. J Mol Evol 16:111120.

Konstantinidis KT, Tiedje JM. 2005. Towards a genome-based taxonomy for prokaryotes. J Bacteriol 187:6258-6264.

Kropat J et al. 2011. A revised mineral nutrient supplement increases biomass and growth rate in Chlamydomonas reinhardtii. Plant J 66:770-780.

Lebonah DE et al. 2014. DNA barcoding on bacteria: a review. Adv Biol 2014:1-9.

Lin L et al. 2012. Characterization of extracellular cellulosedegrading enzymes from Bacillus thuringiensis strains. Electron J Biotechnol 15:1-7.

Liu Y et al. 2017. Proposal of nine novel species of the Bacillus cereus group. Int J Syst Evol Microbiol 67:2499-2508.

López-Campos G et al. 2012. Microarray detection and characterization of bacterial foodborne pathogens. New York City: SpringerBriefs in Food, Health, and Nutrition. Springer.

Marañón E et al. 2005. Continuity in the photosynthetic production of dissolved organic carbon from eutrophic to oligotrophic waters. Mar Ecol Prog Ser 299:7-17.

Nakamura LK, Jackson MA. 1995. Clarification of the taxonomy of Bacillus mycoides. Int J Syst Bacteriol 45:46-49.

Nhu VTP, Diep CN. 2017. Isolation and characterization of endophytic bacteria in soybean (Glycine max L. (Merrill) cultivated on alluvial soil of Can Tho city, Vietnam. IJIET 8:208-221.

Ozdal M et al. 2017. Continuous production of indole-3-acetic acid by immobilized cells of Arthrobacter agilis. 3 Biotech 7:23-28.

Patten CL et al. 2013. Activity, distribution and function of indole-3-acetic acid biosynthetic pathways in bacteria. Crit Rev Microbiol 39:395-415.

Prabaningtyas S, Witjoro A. 2017. Eksplorasi bakteri sinergis dari beberapa danau di Jawa Timur untuk mempercepat pertumbuhan mikroalga renewable energy tahun ke 1 [Synergistic bacterial exploration of several lakes in East Java to accelerate the growth of microalgae renewable energy, 1 st year]. Malang, Indonesia: Universitas Negeri Malang.

Prabaningtyas S et al. 2018a. Eksplorasi bakteri sinergis dari beberapa danau di Jawa Timur untuk mempercepat pertumbuhan mikroalga renewable energy tahun ke 2 [Synergistic bacterial exploration of several lakes in East Java to accelerate the growth of microalgae renewable energy,2nd year]. Malang, Indonesia: Universitas Negeri Malang.

Prabaningtyas S et al. 2018b. Vertical distribution of bacteria in various lakes of East Java, Indonesia.JPhys: Conf Ser 1093:012017. DOI:10.1088/1742-6596/1093/1/012017

Ramanan Ret al. 2016. Algae-bacteria interactions: evolution, ecology and emerging applications. Biotechnol Adv $34: 14-29$

Rasko DA et al. 2005. Genomics of the Bacillus cereus group of organisms. FEMS Microbiol Rev 29:303-329. 
Rooney AP et al. 2009. Phylogeny and molecular taxonomy of the Bacillus subtilis species complex and description of Bacillus subtilis subsp. inaquosorum subsp. nov. Int J Syst Evol Microbiol 59:2429-2436.

Rosselli $\mathrm{R}$ et al. 2016. Direct 16S rRNA-seq from bacterial communities: a PCR-independent approach to simultaneously assess microbial diversity and functional activity potential of each taxon. Sci Rep 6:32165. DOI: $10.1038 /$ srep32165

Rzhetsky A, Nei M. 1992. A simple method for estimating and testing minimum-evolution trees. Mol Biol Evol 9:945-967.

Saitou N, Nei M. 1987. The neighbor-joining method: a new method for reconstructing phylogenetic trees. Mol Biol Evol 4:406-425.

Schloss PD, Handelsman J. 2004. Status of the microbial census. Microbiol Mol Biol Rev 68:686-691.

Shao J et al. 2015. Analysis and cloning of the synthetic pathway of the phytohormone indole-3-acetic acid in the plant-beneficial Bacillus amyloliquefaciens SQR9. Microb Cell Fact 14:130. DOI:10.1186/s12934$015-0323-4$

Spaepen S et al. 2007. Indole-3-acetic acid in microbial and microorganism-plant signaling. FEMS Microbiol Rev $31: 425-448$.

Stackebrandt E, Goebel BM. 1994. Taxonomic note: a place for DNA-DNA reassociation and 16S rRNA sequence analysis in the present species definition in bacteriology. Int J Syst Evol Microbiol 44:846-849.

Susilowati DN et al. 2018. Indole-3-acetic acid producing bacteria and its application on the growth of rice. In: Proceedings of the 5th International Conference on Biological Science. Yogyakarta: AIP Conference Proceedings. pp. 1-9.
Thyssen M. 2005. Spatial distribution of heterotrophic bacteria in the northeast Atlantic (POMME study area) during spring 2001. J Geophys Res 110:1-16.

Tindall BJ et al. 2010. Notes on the characterization of prokaryote strains for taxonomic purposes. Int J Syst Evol Microbiol 60:249-266.

Truong DT et al. 2017. Microbial strain-level population structure and genetic diversity from metagenomes. Genome Res. 27:626-638.

Tshikhudo P et al. 2013. Bacterial species identification getting easier. Afr J Biotechnol 12:5975-5982.

Vilas-Bồas GT et al. 2007. Biology and taxonomy of Bacillus cereus, Bacillus anthracis, and Bacillus thuringiensis. Can J Microbiol 53:673-687.

Wang Y, Qian PY. 2009. Conservative fragments in bacterial $16 S$ rRNA genes and primer design for $16 \mathrm{~S}$ ribosomal DNA amplicons in metagenomic studies. PLOS ONE 4:e7401. DOI:10.1371/journal.pone.0007401

Werner JJ et al. 2012. Impact of training sets on classification of high-throughput bacterial 16s rRNA gene surveys. ISME J 6:94-103.

Woo PCY et al. 2009. Guidelines for interpretation of $16 \mathrm{~S}$ rRNA gene sequence-based results for identification of medically important aerobic Gram-positive bacteria. J Med Microbiol 58:1030-1036. 